\title{
"The Politics of Place": Domestic and Diplomatic Priorities of the Colorado River Salinity Control Act (1974) ${ }^{1}$
}

\author{
Evan R. Ward
}

\begin{abstract}
"The tragedy ... [of the Colorado River Delta] is not just that local populations with the greatest stake in local ecosystems are politically marginalized in process of globalization, but that natural resources are managed not as constituent parts of an ecosystem but as so many separate assets by a host of agencies [, distant communities, and interests]. .."2
\end{abstract}

In August 1973, Special Ambassador Herbert Brownell and Mexican Foreign Secretary Emilio Rabasa brought a sense of closure to twelve years of contentious binational disputes over salinity levels in the Colorado River by drawing up Minute 242 of the Mexican Water Treaty. Since 1961, saline runoff from the Wellton-Mohawk Irrigation District in Yuma County contributed to the deterioration of 80,000 acres of farmlands in Mexicali Valley, Baja California. Minute 242 called for a "permanent solution" to the salinity problem. It also promised American technical and financial consulting expertise during the rehabilitation of farms in Mexicali Valley. Brownell guaranteed that the United States would take steps to purify the drainage water through the construction of a desalination plant in Yuma County, Arizona. The United States also agreed to build a drainage channel to carry water from the Wellton-Mohawk Valley to the Gulf of California, where it would not be able to contaminate Mexican diversions from the Colorado River.

During the ensuing year, the Nixon administration, the State Department, Ambassador Brownell, and a legion of local interests in the Colorado River Basin expressed differing priorities in drafting legislation to carry out the salinity control program. The main purpose of this paper is to analyze those priorities on international, regional (Colorado River Basin), and local (Yuma County) levels. While President Nixon and the State Department simply wanted appropriations to build the desalination plant, leaders of western states used the opportunity to press for additional salinity control measures that would help conserve the Colorado River Basin's ever-shrinking water supply. Closer to the border, farmers, municipal leaders, and Native Americans had more precise reasons for supporting or opposing the desalination plant.

1. Several paragraphs of this paper have been adapted from "Saline Solutions: Arizona Water Politics, Mexican-American Relations, and the Wellton-Mohawk Valley," Journal of Arizona History, Fall 1999, and "Two Rivers, Two Nations, One History: The Transformation of the Colorado River Delta since 1940," Nuestra Frontera, forthcoming in volume 22, July-December 1999. The author would like to thank Lester D. Langley, James B. Greenberg and the reviewers also provided valuable assistance in completing the manuscript.

2. James B. Greenberg, "The Tragedy of Commoditization: Political Ecology of the Colorado River Delta's Destruction," Research in Economic Anthropology, 1998, volume 19:146. 
These various geopolitical perspectives were represented by two sets of bills discussed in the House and Senate. The solution promoted by the Nixon administration and the State Department was set forth in House of Representatives Bill 12384 (H.R. 12384) and Senate Bill 3094 (S.R. 3094). These bills only made provisions for those measures that would solve the immediate problems in Mexicali. Supporters of these bills wanted to construct the desalination plant near Yuma, extend the wastewater drainage channel to the Gulf of California, provide financial and technical assistance for Mexicali farmers, and provide clean water while the plant was under construction. H.R. 12384 and S.R. 3094 also included appropriations for the lining of the Coachella Canal (above the Imperial Valley in California) with concrete to conserve the water that would be needed to fulfill the United States' responsibilities under the Mexican Water Treaty.

In contrast, H.R. 12165 and S.R. 2940 (drawn up by Congressman Johnson [CA] and Senator Fannin [AZ]) included everything mentioned in the administration-sponsored bills (hereafter referred to as Title I), plus an ambitious plan known as "Title II." Title II provided for the construction of a \$34-million groundwater-pumping well field near Yuma, in order to combat Mexican pumping of a binational aquifer. Title II also included millions of dollars for the removal of natural salt sources throughout the basin. Henry Brownell played a critical role in helping national leaders realize that leaders of western states would block international interests unless their local interests were satisfied. When the administration initially objected to Brownell's suggestion that the federal government pay for the desalination plant, he reminded them that without the support of the Basin states "one does not have a solution to the problem with Mexico."3

Ultimately, the complexity manifest during deliberations over the Colorado River Salinity Control Act illustrates that as one moves from the international to the local level, priorities and concerns become more precise and complicated. Furthermore, local and international priorities are often more at odds with each other than are the priorities of any other two levels of government. Daniel Kemmis summarized this political reality best when he wrote, "[The] political culture of a place is not something apart from the place itself." 4

\section{The Western Diplomat: Herbert Brownell and Minute 242}

In hindsight, Richard M. Nixon's appointee, Herbert Brownell, proved to be an appropriate choice for the job of special ambassador to resolve the salinity problem with Mexico. A successful lawyer in international business, Brownell was appointed by Dwight D. Eisenhower to serve as attorney general in 1953. His experience in natural resource litigation as Attorney General allowed him to work closely with the leadersof western states. He observed that during the Eisenhower administration "states rights were giving way to the assumption by the federal government of preeminence in [the] field" of natural resources. ${ }^{5}$ Brownell noted that this was most evident in water law, as "Congress had not yet enacted comprehensive federal environmental laws, and the states in the Western part of the country still fought for exclusive control of water rights." ${ }^{\text {"6 }}$ Brownell gained most of

3. Philip Fradkin, A River No More: The Colorado River and the West (New York:

Knopf, 1981), 313.

4. Daniel Kemmis, Community and the Politics of Place (Norman: University of Oklahoma Press, 1990), 7.

5. Herbert Brownell Advising Ike: The Memoirs of Herbert Brownell, 155. 
his knowledge of western water politics while he worked on the Arizona vs. California case. This landmark case determined the apportionment of water from the Colorado River for Arizona, California, and the native tribes along the river. Given this experience, Nixon assigned to Brownell the difficult task of drafting Minute 242 with Mexican officials. This required a balance of shrewdness and deference, given the history of Mexico's approach to Mexican-American relations. Although the salinity crisis did not represent a major event in American diplomacy, Mexican leaders, particularly President Luis Echeverria, used the problem to reinforce Mexican nationality. ${ }^{7}$

Brownell's legal background provided him with extensive experience, yet his western roots, fascination with technology, and faith in progress, help explain the course he pursued in dealing with the governments of western states and the Mexican government. Brownell grew up in rural Nebraska. His exposure to a modern agricultural society attuned him to the mentality that prevailed among farmers in the west. At the House hearings Brownell confessed:

It is a temptation, of course, for me, being interested as I always have since my early days in the development of the West, the Middle West, where I came from, to urge the most prompt action in any area that will assist development of the natural resources there. ${ }^{8}$

This mentality not only benefited Brownell in dealing with Western politicians, but it ultimately benefited the Westerners and Mexicans. In sum, they were dealing with a man who believed in large-scale agricultural development.

Brownell's interest in using science to promote natural resource development also played a critical role in the scope of the agreement reached between the two countries. While he consulted with an expert "task force" throughout the negotiations, Brownell's personal fascination with technology likely played a notable role in crafting the solution envisioned in Minute 242. In his memoirs he remembered the scientific perspective that his father instilled in him from an early age. He observed: "Through my high school and college years, my father taught me at home and in the class room the importance of respecting 'the scientific method' when pursuing the mysteries of life and of the universe in the laboratory and observatory." 9 The desalination plant proposed for construction in Yuma subtly blended Brownell's love of technology with his understanding of western water politics. He took pride in the fact that he helped "find innovative ways to resolve bilateral problems in our relation with Latin America." 10 Furthermore, since the plant would purify wastewater without the use of large volumes of additional water, farmers and communities throughout the West would not have to worry about curtailing diversions

\section{Ibid.}

7. Alan Riding, in Distant Neighbors, (New York: Vintage Books, 1989), has written, "It is as if Mexican politicians and journalists need some relatively simple issue on which to focus their infinitely more complex sentiments about the United States," 336.

8. Subcommittee on Water and Power Resources, Hearings Before the Subcommittee on Water and Power Resources of the Committee on Interior and Insular Affairs, House of Representatives, 93rd Congress, 2nd Session, HR 12165 and Related Bills, Colorado River Basin Salinity Control Act, (Washington: GPO, 1974), 128.

9. Brownell, 3 . 
from the river. Representatives from the desalination industry also received a financial boost from Brownell's faith in technology. The cost of the plant would escalate from an estimated \$120 million in 1974 to $\$ 260$ million (not including operation costs) by the time of its completion in 1993.

\section{The River before Watergate: Nixon, The State Department and Minute 242}

Given the level of U.S. involvement in Southeast Asia, it is not surprising that President Nixon and the State Department adopted a minimalist approach in resolving the salinity crisis. Nevertheless, by 1974 American leaders began to feel pressure to end the embarrassing debacle. William Bowdler, Deputy Assistant Secretary of State for InterAmerican Affairs, reflected on his uncomfortable excursions to Mexico on official business: "Whenever an issue arose in our relations with Mexico, whenever opportunities appeared for cooperation between the two governments, when our parliamentarians met in joint meetings, the salinity problem invariably confronted our spokesmen." ${ }^{11}$ Stewart Udall marveled at the general knowledge of the problem throughout Mexico. "I was amazed when I first got there," he recalled, "I thought this was probably a grievance in Baja California, and Sonora, perhaps; but you talk to some fellow from Guadalajara or Yucatan and this is the first thing they bring up." ${ }^{12}$ Udall also noted the abundance of complaints concerning the quality of water that the United States delivered to Mexico during the three previous decades. Mexicans complained that the United States had allowed "raw sewage, industrial wastes, hydrochloric acid and whatever" to be included as part of the 1.5 million acre-feet contract. As these statements illustrate, the crisis transformed "good neighbors" into reticent strangers. "There has been, over the years, some insensitivity," Udall observed, "in the way we have handled this with our neighbors." 13 The administration and the State Department advocated H. R. 12384 and S.R. 3094 in order to keep the cost as economical as possible. The Department of the Interior and the EPA also endorsed the administration's bills, yet for different reasons. Neither organization had completed their own full-scale study of salinity in the west and did not want to apply for appropriations until those investigations had been completed. ${ }^{14}$

\section{“Total Shutdown": Environmental Response to Colorado River Salinity Problems}

Perhaps no event better represented the monumental transitions in western water politics than the debate over the Colorado River Salinity Control Act. From the early twentieth century until the 1960s, congressional hearings dealing with water projects in the Lower Colorado River Delta mainly attracted the attention of those who had the most

10. Subcommittee on Water and Power Resources, Hearing before the Subcommittee on Water and Power Resources of the Committee on Interior and Insular Affairs, United States Senate, 93rd Congress, 2nd Session, S. 1807, S. 2940, S. 3094, Salinity Control Measures on the Colorado River, (Washington: GPO, 1974), 116.

11. House Hearings, 95.

12. Ibid., 213-214.

13. Ibid.

14. House Hearings, 88-89; Senate Hearings, 46-50. 
to gain from them, namely western farmers, municipal leaders, their congressional representatives, and well-paid lobbyists. In addition to these groups, environmental organizations participated in the Colorado River Salinity Control Act hearings. Eschewing the tactics of radical environmental groups, the Sierra Club and national think-tanks sent representatives to Washington to deal within the political system to bring about change. ${ }^{15}$ It is not surprising, however, that the environmentalists elicited little attention from the House Committee.

The two environmental groups represented had little interest in seeing either set of bills passed. In contrast to the pragmatic approach of Western leaders and the administration, Brent Blackwelder (Environmental Policy Center) and John McComb (Sierra Club) objected to the developmental nature of the Control Act and the lack of Western responsibility required by either of the bills. Blackwelder contended that those who would benefits from the project should "shoulder a major share of the costs of cleanup."16 Blackwelder and McComb also advocated the dissolution of the Wellton-Mohawk project. Not only would this be the most environmentally sound method to solve the problem, it would apply the brakes to run-away federal spending meant to prime the pump of commercial agriculture. Blackwelder claimed that only one million of the $\$ 50$ million owed by the farmers in the Wellton-Mohawk region had been repaid to the government. "It seems incredible that the taxpayers of the Nation are now being asked to spend many millions more, possibly as much as $\$ 200$ million in the long run," Blackwelder observed, "to remedy the problems occasioned by this district." 17

Blackwelder and McComb also urged House leaders to reflect on the project's track record. In suggesting the partial or total shutdown of the Wellton-Mohawk District, McComb appealed to the past performance of the district. "The irrigation project has been plagued by problems from its very inception," he observed, "and we seriously question the wisdom of any further unnecessary expenditures of federal funds in order to keep it in operation." McComb objected to the wasteful amount of energy that would be necessary to run the desalination plant. They suggested that the United States Bureau of Reclamation (USBR) use more prudent methods of reducing salinity, such as "limiting further water resource development." 18

Environmentalists and western officials did agree on one crucial aspect: the need for increased salinity control throughout the basin. They were divided, however, on which sources should be eliminated. Western farmers wanted to remove natural salt sources. In contrast, The Sierra Club wanted to cut back on "man caused increases in salt load." This would include farms operating in locations such as the Wellton-Mohawk Valley, where poor drainage conditions exacerbated salinity levels in the Colorado River. McComb also posited the aesthetic value of several locations targeted for containment under Title II. Blue Spring, Colorado, was "an integral part of the Grand Canyon in addition to being spectacular in its own right." He also reminded the committee that the area served as a religious site for Indian tribes along the river. The concept of environmental and cultural

15. For a discussion of transformations in environmental approaches to pursuing change in the American political system see Kirkpatrick Sale, The Green Revolution: The American Environmental Movement, 1962-1992 (New York: Hill and Wang, 1993).

16. House Hearings, 306.

17. Ibid.

18. Ibid., 311. 
preservation stood as one of the trademark purposes for the existence of the Sierra Club. Two decades earlier the Sierra Club scored a major victory in their quest to preserve Echo Park, in Utah's Dinosaur National Monument Park. When it was announced that the USBR would build a dam there, Sierra Club president David Brower creatively galvanized public support against the project. In the 1960s a relentless ad campaign in The New York Times not only prevented construction of a dam that would have inundated part of the Grand Canyon, but also invoked the wrath of the federal government against the organization. Thereafter, the IRS threatened to revoke the club's non-profit status. ${ }^{19}$ The idea of natural preservation for the sake of beauty reflected a growing desire for preservation of natural settings as an escape from the industrial/technological domination of American society. ${ }^{20}$

McComb believed that members of the general public would be open to cuts in water usage throughout the Colorado River Basin, yet such changes were not politically feasible. He was much more realistic in his assumption that any limitations of western water consumption would be considered "heresy or a denial of some absolute right by the water resource development agencies." 21 The binational nature of the current diplomatic predicament gave western states political leverage that the USBR never had in fighting against the Sierra Club over Echo Park Dam. First, Brownell and the administration were working under a time limit. The legislation had to be approved by July 1, 1974. Furthermore, the Western states could easily block passage of Title I until their demands for comprehensive salinity control were met.

\section{"We Can Make Money From It": The Desalination Industry and Minute 242}

Numerous avenues for reaching a permanent solution to the salinity crisis were explored. Possibilities included building a desalination plant, seeding clouds, buying out the land of farmers in the Wellton-Mohawk District, or substituting better water from the Imperial Dam. ${ }^{22}$ So, why the decision for the most costly solution? As the Cold War heated up in the early 1950s, Congress passed the Saline Water Act (1952) "to provide for the development of practicable low cost means of producing from sea-water, or from other saline waters, water of a quality suitable for agriculture, industrial, municipal, and other beneficial consumptive uses. . ."23 While the Office of Saline Waters (OSW) would function as a part of the Department of Interior, the 1952 act also called for cooperation with the Department of Defense. After 1952, corporations and labs traditionally associated with the "military-industrial complex" received contracts to develop desalination techniques and oversee construction of plants domestically and throughout the world. High energy costs, however, constantly plagued the OSW's quest to achieve aquatic

19. Marc Reisner, Cadillac Desert: The American West and Its Disappearing Water, (New York: Viking, 1986) 296-297.

20. Samuel P. Hayes, Beauty, Health, and Permanence: Environmental Politics in the United States, 1955-1985, (Cambridge: Cambridge University Press, 1987), 2-5

21. House Hearings, 311.

22. Ibid., 81-82.

23. See "Appendix A-Authorization," in Saline Water Conversion Summary Report, 1971-1972, Office of Saline Water, US Department of the Interior (Washington: GPO, 1972), 51. 
alchemy. Most importantly, the tantalizing promise of virtually free power from nuclear desalination plants never materialized. After plans for several plants in the Pacific Southwest failed to materialize, the OSW considered the Colorado River Salinity Crisis as an appropriate case to test the merits of their new "reverse osmosis" filtration system. In sum, expediency and extensive investments over the course of two decades explain much of the decision to build a desalination plant in the middle of the Sonoran Desert.

In May 1975, Editor Ken Lucas wrote a scathing article about the proposed desalting plant for the Arizona Farmer-Ranchman. He argued that little planning went into the decision to build the plant. In support of his assumption, Lucas alleged that USBR officials only realized that Yuma and the Imperial Valley lay near the San Andreas Fault line after appropriations for the plant had been approved. In reality, however, policy makers knew that the plant lay near the San Andreas Fault because a joint Mexican-United States commission, under the auspices of the International Atomic Energy Agency, originally had explored construction of a binational nuclear desalination plant in the Golfo de Santa Clara (near San Luis Rio Colorado, Sonora, Mexico) in the late 1960s. ${ }^{24}$ Proximity to the Fault ruled the site out and the Yuma sight was subsequently selected by the USBR and the OSW as suitable for a nonnuclear desalination plant.

Lucas also claimed that the plant was an unnecessary project conceived to assist the fledgling desalination industry. If the plant was successful, American firms could tap into water-starved Arab markets. Yet immediate economic considerations, he noted, also motivated the desalination industry. Companies like Universal Oil Products Co. stood to gain a great deal through government contracts on the Yuma plant. ${ }^{25}$ Brownell concurred with this interpretation when he observed: "[T]he construction of the world's largest desalting plant, provides a decided boost to desalting technology which cannot but have significant effect elsewhere in the United States and, indeed, in the world." ${ }^{26}$ These linkages between private industry and the government were not lost on developers of desalination technology. William Warne, former Assistant Commissioner of the Bureau of Reclamation, represented the National Water Supply Improvement Association at the House hearings. Warne gave the association's definitive stamp of approval for the plant during his presentation to the committee. ${ }^{27}$ Ultimately, The desalination companies were the biggest economic winners from the Colorado River Salinity Control Act.

\section{"Charity Begins at Home": Western Interests and Mexican Diplomacy}

If 1890 marked the end of the territorial frontier of the United States, then 1968 signaled the close of a more fluid frontier in the Colorado River Basin. In the same year Richard Nixon was elected to the presidency, Congress approved the Central Arizona

24. See Nuclear Power and Water Desalting Plants for Southwest United States and Northwest Mexico, Preliminary Assessment Conducted by the Joint United States-Mexico-International Atomic Energy Agency Study Team, Executive Summary, September 1968, Atomic Energy Commission (Washington: GPO, 1968).

25. Letter from C. C. Tabor to Ken Lucas, May 22, 1975, John J. Rhodes Papers, MS 2, Box 130, Folder 19, Hayden Library, Arizona State University (ASU). Also see Arizona Farmer-Ranchman, May 1975, "Desalting the Wellton Mohawk."

26. House Hearings, 116.

27. Ibid., 286-287. 
Project (CAP), which would use Arizona's remaining surface water from the Colorado River. With that project approved, all of the surface water in the lower basin of the river was legally apportioned to interests within the different states and Mexico. The growing threat of high levels of salinity in the river forced officials to devise a program that would ensure a sufficient water supply to meet those needs without having to sacrifice water to dilute highly saline river flows. The Colorado River Salinity Control Act provided a new approach to maximizing the annual water supply throughout the basin. Cleaning up natural salinity sources throughout the upper basin would not only appease Mexican interests at the river's "drain," but also protect the needs of water users throughout the basin. A representative from the Imperial Irrigation District summed up this political transformation when he observed, "Environmental concerns impel us toward greater efficiencies in the use of our water supplies, toward reclamation reuse of water in order to extend the supplies, and toward conjunctive management of surface and groundwaters." 28

The new sensitivity of westerners to environmental issues had less to do with a newfound enthusiasm for environmentalism than with the need to preserve large-scale agribusiness and municipal growth in the arid Southwest. Nothing attests to the developmental nature of these proposed "environmental" measures better than the plans made for curtailing salt diffusion from the Crystal Geyser near Green River, Utah. Instead of capping the geyser, Western officials proposed that a dike be constructed to contain the effluent. Officials assured the Senate Committee that the dike would "blend with the exposed sandstone for esthetic purposes." Always sensitive to the demands of tourism, officials boasted: "Because of the return of a portion of the erupted water to the geyser, the interval between eruptions would be reduced from 5-6 hours to 2-3 hours, increasing its value as a tourist attraction." Thus, manipulating nature in an effort to "purify" the river ultimately served more than one economic interest. ${ }^{29}$

With a wide spectrum of developmental priorities throughout the basin, almost all of the western interests involved in the debate over the Salinity Control Act recognized that maximizing river resources demanded greater unity amongst regional officials than had prevailed in the past. John Tunney, Congressman from California, acknowledged the linkages between greater cooperation and the altered dynamics of regional water politics. "There has been an unprecedented era of cooperation and mutual effort among the seven states," he noted, "following more than half a century of controversy and bitterness. This bill represents one more step in this new approach along the Colorado, and I am delighted to be able to cooperate in that effort." Tunney's remarks are even more remarkable, considering that only ten years earlier Arizona and California ended a bitter battle over apportionment of water in the lower basin. California lost a significant amount of surplus water to Arizona in that decision. Western states, however, adjusted to shifting circumstances in an effort to protect their existing (and future) interests within the context of regional, national, and international relations.

In addition to adapting their political approach to the constraints of shrinking natural resources in the basin, Western politicians also abandoned their traditionally antagonistic attitude towards Mexico's water rights in the Colorado River basin. Neil M. Cline of the Orange County Water District, for example, expressed "sympathy with our good neighbors in the Mexicali Valley." Noting a precipitous rise in salinity in over-tapped water

28. Senate Hearings, 291.

29. Ibid., 227. 
resources in his own district, Cline observed, "we know what they have been suffering because our situation is much the same as theirs." ${ }^{30}$ A similar tenor marked the rhetoric of Governor Williams (Arizona). Traditionally, Arizona cast an imperious shadow over Sonora and Baja California. On this occasion, however, Williams implied that geographic proximity encouraged a close relationship with Mexico. "I lived right next to the great nation of Mexico as a neighbor," he intoned, "and the solution of course, is very pleasing to our neighbor." 31 Finally, the San Diego Water authority cited "our continuing and close relations with the Republic of Mexico" as the reason why Title's I and II should be approved.

Context, however, further illuminates the multi-dimensional motives of Western leaders for championing the act. Cline's water district relied on the Colorado River for seventy percent of their municipal supply. He observed that "our district serves about $1,500,000$ people in the rapidly urbanizing Orange County." 32 "The salinity project would offset the expenses that consumers were currently paying to control salinity in the water supply. ${ }^{33}$ In Williams's case, reference to the "neighborly" nature of border relations was couched within a request for greater federal help for the western states. With the Mexican issue solved by Title I, it was "up to those who created the solution to find some relief for the seven states that are threatened. ${ }^{34}$ Likewise, the City of San Diego pushed for passage of Title II as part of a "permanent solution to the salinity problem with Mexico." Ironically, their letter in favor of the bill dealt almost entirely with the benefits that the proposed legislation would provide for the City of San Diego. ${ }^{35}$

Finally, whether they would admit it or not, officials from western states had much in common with Mexican officials in terms of their relationship with Washington. They were all largely dependent on federal assistance for development of reclamation projects in the Colorado River Basin that would ameliorate water quality throughout the watershed. Politicians from western states exploited their self-imposed identity as "second-class" Americans in seeking approval for Title II salt control. Congressman Craig Hosmer (California), for example, cited the government's treatment of the Colorado River Basin during negotiation of the Mexican Water Treaty in the 1940s as an example of federal neglect. Hosmer claimed that President Franklin Roosevelt "got a big concession on the Rio Grande out of the Mexicans and he gave away the Colorado River water to the Mexicans in quantity...There was not really much attention paid to the Colorado River at that time," he complained. Past presidents, he argued, did not understand the value of water in the West. Hosmer particularly despised: "The high-handed way in which Presidents seem to go down and get an 'embracio' and then come back and give away some of the West's water to somebody. That is not exactly something that to my mind is a bargaining chip."36

Hosmer's testimony reflected the feelings of many westerners towards Mexico and the federal government. Senator Bible from Nevada also felt there was a critical need for

30. House Hearings, 289

31. Ibid., 167.

32. Ibid., 289.

33. Ibid., 290

34. Ibid., 167.

35. Senate Hearings, 313-315.

36. House Hearings, 215. 
federal help in the West. "I think it is our responsibility to take care of those people in the West that have the same salinity problem that is inherent in the international phase of it," he opined. "I have always felt that charity begins at home." ${ }^{37}$ Senator Paul Fannin (Arizona) expressed similar ideas. Taking care of Mexico only alleviated half of the problem: "I don't see that we should have irreparable damage come about for U.S. citizens just to allow the citizens of Mexico to benefit by it." 38 Senator Towell from Nevada encouraged the Committee to "live up to [their] obligations of our own individual states," as well as satisfy the various treaties with Mexico. ${ }^{39}$ Some westerners pledged their support for the salinity plant only if "something is done on behalf of our own water users." ${ }^{40}$ Evoking memories of an old-fashioned stagecoach hold-up, Congressman Johnson (California), took issue with the State Department's objections to Title II: "It is not our intention to try to hold up anything or hold anybody at gunpoint. We would, however, like to have consideration and recognition given to our problems. We will try and perfect you a good Title I to take care of the international problem, and we would like to have a Title II in the bill that would help give us a little boost on the problems of the American side of the border ..."41

Finally, some leaders of western states cited the interdependent nature of relations between Mexico and the western United States in their arguments for the Salinity Control Act. These leaders insisted that if Title II were not adopted, the impact could be "as injurious to Mexican as it is to United States water users." 42 Wesley Steiner linked the fortunes of Mexico to both the Lower and Upper Basin in the United States. Steiner warned the committee of the impending costs of a narrow approach to the salinity crisis: "Without the control of upstream salinity, the U.S. will be faced with a new salinity problem in Mexico as salinity levels increase with continued development; and water users in the United States will suffer significant economic impacts, with impacts estimated to reach $\$ 80$ million annually by the year $2000 ., 43$

Western leaders also continued their historic pattern of federal dependence by insisting that the government pay for $75 \%$ of the Title II program. This strategy, in reality, was an effort to turn recent legal decisions concerning jurisdiction over waters of the Colorado River to the advantage of the western states. Through a series of court decisions during the mid-twentieth century, the states failed to gain control of the riverbed. ${ }^{44}$ While this served as a blow to the cause of western "independence," it proved to be a powerful tool in arguing for federal funding of the Act. Wesley Steiner argued that the federal government was the only organization involved "in all major aspects of the salinity problem." 45

37. Senate Hearings, 181-182.

38. Ibid., 185.

39. House Hearings, 116.

40. Ibid., 75 .

41. Ibid., 133.

42. Ibid., 96,192.

43. Ibid., 189.

44. Donald J. Pisani, "The Irrigation District and the Federal Relationship: Neglected Aspects of Water History," in The Twentieth-Century West: Historical Interpretations, edited by Gerald D. Nash and Richard Etulain, (Albuquerque: University of New Mexico Press, 1989), 257-292.

45. Senate Hearings, 231. 
Therefore, he reasoned, it should "finance the salinity control project and . . .bear a major share of the repayment responsibility." 46 Other organizations felt that the federal government should shoulder a major portion of the project since many Western organizations had already spent millions of dollars combating river salinity. ${ }^{47}$

Numerous interests throughout the basin clamored for federally - funded salinity control projects. The Committee of Fourteen, a group of Western leaders that advised Brownell, warned that the initiation of large-scale oil shale projects would further exacerbate the salinity crisis. Chairman Steiner pointed to the environmental impact statement drawn up for the shale operations as a precedent for federal help in controlling salinity levels. ${ }^{48}$ Other organizations testified about the harmful effects of saline water that could occur in their localities. Farmers in San Diego County cultivated crops that were highly sensitive to saline water. "If the salinity in the Colorado River water rises significantly," officials noted, "the Authority's farmers will find it difficult to continue in production." Saline water from the Colorado River was already beginning to take its toll on homes and the sewer system in San Diego. "Current estimates of the cost due to excessive levels of corrosion in water heaters and other plumbing facilities," The SDWA estimated, "range from \$10 million to \$20 million per year for San Diego water users." 49 In sum, numerous Western interests viewed Minute 242 as an opportunity to win approval for a comprehensive plan that would provide greater protection for further development in the Southwest.

\section{Life on the River}

Understanding the nature of water politics in the Colorado River Basin is best accomplished by tossing a stone into a placid body of water. The stone enters the water, creating a concentric ripple that moves away from the point of contact. Each new ripple is generated with a different level of force and velocity. While the point of contact and the series of ripples are related, they are unique in that specific properties generate each new impression. In water politics, a problem, such as the salinity crisis, serves as the stone. Its impact on the local level (Yuma County), throughout the Colorado River basin, and in international relations, generates unique yet interrelated problems. Yet the crisis, like the splash of the stone, creates its most jarring effects closest to the point of contact. Ironically, the complexity of Yuma County water relations made the process of finding a simple solution to basin-wide concerns more difficult. What would be best for Mexico or for the State Department was not necessarily the ideal arrangement for Yuma County farmers or the Cocopah natives. Within Yuma County organizations such as the WelltonMohawk District, the Yuma County Water Users Association, the City of Yuma, and the Cocopah Indian Tribe, members expressed their support or disapproval of the bills based on their individual priorities. Ultimately, their numerous approaches to development of the Delta region demonstrated the complexity of local relations in coming to terms with an international problem.

46. Ibid.

47. Northcutt Ely, attorney for the Imperial Irrigation District (IID), stated, "we feel it is appropriate, as well as timely, for the United States to do its part to reduce salinity of the waters reaching us." House Hearings, 292.

48. Ibid., 180.

49. Senate Hearings, 313-314. 


\section{Reconstructing Wellton-Mohawk}

Farmers and officials in the Wellton-Mohawk Valley felt they had the most to lose through the Colorado River Salinity Control Act. While environmentalists urged the House and Senate committees to completely dismantle the Wellton-Mohawk District, more conservative voices prevailed. Headed by the Committee of Fourteen, which included Tom Choules, a member of the Welton-Mohawk Irrigation Drainage District (WMIDD), western farm interests rallied to protect the embattled project. The words of Henry Brownell encouraged Western politicos. He assured the Committee that "water users in the U.S. would not suffer from the results of this legislation." ${ }^{, 50}$ Nevertheless, the bill provided for the retirement of 10,000 acres of unproductive land on the project. Recognizing the necessity for compromise, WMIDD leaders worked to preserve the water rights they had been granted for 75,000 acres of land, even though the project would only include 65,000 acres after passage of the bill. Choules noted, "We are using about 300,000 acre-feet of water . . at the present time to irrigate less than 65,000 acres." ${ }^{, 51}$ Choules suggested that the language of the bill protect the water rights of the district. C. C. Tabor, WMIDD Manager, also presented this request to the Senate Committee Hearings. ${ }^{52}$

The long-term effects of the crisis took their toll on the leaders of the WMIDD. Intense international, domestic, and state scrutiny contributed to a feeling of victimization. Choules feared that the Salinity Control Act would ultimately endanger his district. "We could end up not only at the tail-end of the ditch," he observed, "but getting worse water and worse treatment as a result." ${ }^{53}$ Skeptical about the effectiveness of the desalination plant, Choules quipped, "We are going to be the guinea pig under the act through the means of sizing the desalting plant." ${ }^{, 54}$ Choules completed his testimony by suggesting that if WMIDD drainage water had not been dumped into the Colorado River about the same time water delivery to Mexico had been reduced in the 1950s, responsibility for the crisis would have been more evenly distributed throughout the basin. "It just happened that those two coincided, and we, being at the tail-end of the ditch, and near as well having been there at that particular time, the finger is pointed at us. ${ }^{, 55}$

Manager C. C. Tabor expressed similar feelings the following year as liquidation of the 10,000 designated acres took place. Tabor continued to believe that the solution for the problem lay in rehabilitating run-down fields and irrigation systems in Mexicali Valley, not building a desalination plant near Yuma. Although the WMIDD retained the rights to 300,000 acre-feet of water, Tabor complained that the new Central Arizona Project would demand that they not exceed that total, as they had in previous years. Finally, Tabor lamented the continued presence of government employees on the project. "No pleasure is derived from being swarmed over by federal employees," he lamented. Even though the district lobbied for negotiated liquidation of the retired lands by the USBR, "purchase of the 6,000 acres of private ownership by the [USBR]" proceeded at a snail's pace. ${ }^{56}$

50. House Hearings, 262.

51. Ibid., 261.

52. Senate Hearings, 284-285.

53. House Hearings, 262.

54. Ibid.

55. Ibid., 267.

56. Letter from C. C. Tabor to Ken Lucas, May 22, 1975, John J. Rhodes Papers, MS 2, Box 130, Folder 19. 


\section{"Domestic Use and Human Consumption": Yuma City Water Woes}

What had been a time of frustration for some, was a time of opportunity for others. Even in the staid confines of a congressional hearing room, something of a boom-town mentality prevailed amongst its western participants. Except for a few organizations, namely the WMIDD, most western states and Mexico stood to gain from construction of the desalination plant and implementation of the comprehensive control project. Not the least of the groups impacted was the City of Yuma. Its struggles during the crisis have generally been overlooked as historians have focused almost exclusively on the impact of the salinity crisis in Mexicali. Yuma's domestic water supply, like that of Mexicali, had been contaminated by saline water from the Wellton-Mohawk Valley in 1961. Journalist Lenora Werley observed that Yuma residents "found that the water [was] not pleasant to drink, that it [was] harmful to lawns and garden and that it damage[d] air conditioning pumps and industrial machinery." Werley perspicuously noted that the city's water woes predated the salinity crisis in 1961. Due to the increased use of water throughout the entire Colorado River Basin, the river only carried "a small amount of water when it [got] to the most southwestern city in Arizona." The contaminated run-off from Wellton-Mohawk aggravated the poor quality of the water supply. Werley emphasized the irony of the situation. Yumans, like residents of Mexicali, were incensed by the increased salinity. Geographic isolation, however, made it more difficult for Yumans to vent their complaints. Werley observed, "Some Yumans have thought of marching on somebody like their suffering Mexican counterparts. But who do you march on? The nearest U.S. Consulate is 54 miles away in salty Mexicali., 57

Yuma's domestic water crisis developed as the result of a plan hatched by city leaders during the late 1950s to gain control of enough water from the Colorado River to assure the community's continued growth until the end of the century. City leaders convinced the Secretary of the Interior in 1959 to award the City of Yuma an additional 50,000 acre-feet of water per year from the Colorado River. City Manager Mulford Winsor III based his conclusions on a recent study that the state had conducted regarding domestic water use. According to the results, by the year 2000, Yuma would have a population of 180,000 and consume a little over 50,000 acre-feet of water per year. Winsor also argued that the extreme heat of the Sonoran desert necessitated additional water supplies. "The City of Yuma probably has the highest per capita use of air conditioners of any city in the United States," Winsor averred, " [and] Most of these air conditioners require water in their operation. This is in addition to the domestic requirements experienced in most other areas of the United States." 58 Growth forecasts suggested that construction trends in Yuma favored suburban-style, single-family homes. Accordingly, new lawns would also demand a drink from the Colorado River. The proposal for 50,000 acre-feet of water from the Secretary of the Interior was approved in 1959, over vigorous protest from proponents of

57. Lenora Werley, “U.S. Takes Sudden Interest in Mexicali Water," December 17, 1961, The Arizona Daily Star, Carl Hayden Papers, MS 1, Box 253, Folder 8, Hayden Library, ASU.

58. "Statement of Mulford Winsor, Jr., City Engineer, City of Yuma, Arizona," November 23,1959, presented before the Secretary of the Interior, Phoenix, AZ, 9, Winsor Family Papers. 
the Central Arizona Project. They feared that any further allotments of water from the river by the federal government would ultimately jeopardize the Central Arizona Project. ${ }^{59}$

Thomas Allt, a representative from Yuma, appeared before the House Committee. He noted that Yuma had taken its water directly from the river from 1892 until 1961. During 1961, the USBR released drainage water from the Wellton-Mohawk District into the Gila River. At the confluence with the Colorado River, the water infiltrated the city's intake system and contaminated the water "to the point where it could not be used for domestic purposes and human consumption." ${ }^{, 60}$ In an effort to find a better source for water, the city contracted with the Yuma City Water User's Association (YCWUA) to purchase cleaner water that was released from Imperial Dam and then transported to Yuma Valley via an underground siphon that ran beneath the river bed of the Colorado River from California to Arizona. Nevertheless, the cost of obtaining water from the siphon vis-à-vis the original intake system was prohibitive. Faced with few options, Allt quipped, "We right now are in a position where they own the taxi and we want a ride, we've got to pay the bill." The city's predicament illustrated how a regional crisis, though international in its implications, produced peculiar problems and tensions on the local level.

The argument posed by Allt as to the source of the problem followed a pattern similar to that employed by other state and regional leaders at the time. Allt contended that the City of Yuma was not responsible for the recent crisis which had been "imposed on them by circumstances beyond their control." He expressed resentment towards the USBR for their failed attempts to extricate farmers in Wellton-Mohawk from their salt-stricken fields and wells. Nevertheless, "What was of great benefit to the Wellton-Mohawk area," Allt observed, "was economically detrimental to the city of Yuma, in the added cost to acquire raw water." ${ }^{\prime 1} \mathrm{He}$ also contrasted federal treatment of Yuma and Mexico while explaining the plight of Americans in the Delta. Allt argued that whereas little had been done to alleviate the domestic water situation in Yuma, the State Department was feverishly attempting to assuage similar complaints by Mexicans in Mexicali. ${ }^{62}$ Pleading for domestic equity, Allt asserted, "we are disturbed that the people of Yuma should bear a disproportionate part of the burden when the very cause which creates a problem for Mexico also caused an economic problem for the city of Yuma." ${ }^{33}$ In compensation, Allt believed that the City of Yuma should receive priority rights to buy excess water purified by the desalination plant. He suggested that the bill be amended to allow the city the first possible opportunity to purchase excess water purified by the desalination plant. ${ }^{64}$

\section{YCWUA and the Bi-National Aquifer}

YCWUA leaders developed an interest in the Salinity Control Act because of recurring drainage problems that had threatened Yuma Valley since the second decade of the twentieth century. A rising water table underneath the valley floor, due to poor drainage conditions and intensive irrigation, periodically threatened local agricultural production.

59. Central Arizona Project Association Papers, MS 100, Box 29, Folder 6, Hayden Library, ASU.

60. House Hearings, 252.

61. Ibid.

62. Ibid.

63. Ibid., 253 .

64. Ibid. 
As early as 1912 drainage pipes and wells were installed in the valley. Wastewater was sold to Mexican interests at the international boundary near San Luis Rio Colorado. The Mexican Water Treaty of 1944, however, raised the prospect of increased drainage problems. The Mexican government successfully petitioned to build a diversion dam, Morelos Dam, at the international border adjacent to Yuma Valley. President Henry Freuenfelder and other members of the YCWUA Board of Governors vigorously protested construction of the dam because they felt it would contribute to their drainage problem. ${ }^{65}$

YCWUA leaders miscalculated the impact of Morelos Dam. Great care was taken by the International Boundary and Water Commission to protect Yuma Valley from any problems Morelos Dam might have caused. Nevertheless, similar precautions were not taken with the constructed the Gila Irrigation Project, which linked the Colorado River to Yuma Mesa and the Wellton-Mohawk region. Irrigation of Yuma Mesa began in the early 1950s and excess water seeped into the aquifer beneath Yuma Valley. At a special hearing on Yuma's drainage problems in 1956, Ernest Johannsen, President of the YCWUA, argued that the valley's drainage problems did not begin until water delivery began on the Yuma Mesa. The Mesa overlooked the eastern side of Yuma Valley. A special report prepared to assess Yuma Valley's drainage situation concluded that:

The problem cannot be confined to a limited area. It has a regional aspect. The hydrological region now involved and to be involved to a greater extent in the future includes the Wellton Mohawk area to the east, the South Gila area, the Yuma Mesa, the Yuma Valley, and Mexico. . . Most of this region is underlain by a highly transmissive coarse-gravel aquifer, the top of which is about at sea level. It is believed that this aquifer is a controlling factor in the underground hydrology of the region. ${ }^{66}$

Ironically, Yuma's greatest problems could largely be attributed to developments in the United States portion of the Colorado River Delta and not to the new Mexican dam.

From the 1950s until passage of the Colorado Salinity Control Act, leaders from the YCWUA argued that the federal government was responsible for drainage problems in the valley. Johannsen testified at the 1956 hearings that local farmers refused to take out loans to alleviate the groundwater problem, because "it [was] not caused by irrigation operations in this district." ${ }^{67} \mathrm{He}$ dramatized the severity of the problem, claiming that groundwater was "boiling up under our feet." YWCUA leaders expressed their belief that the government should pay for the installation of drainage wells in the eastern section of the valley to prevent further infiltration of the valley aquifer by seepage from farms on the Yuma Mesa. At the time, neither the USBR nor members of the committee believed that the drainage problems merited federal help. Engineer C. E. Jacobs contended that more studies were needed prior to approving federal aid to bail out farmers. Charles Maierhofer, USBR Chief Drainage and Ground Water Engineer, conceded that water was affecting

65. Letter from Henry Freuenfelder to Carl Hayden, January 12, 1945, YCWUA Historical Files; Letter from Freuenfelder to Ernest W. McFarland, March 27, 1944, YCWUA Historical Files.

66. United States Senate, Committee on Interior and Insular Affairs, Yuma Arizona Groundwater Problems, Hearings, (Washington: GPO, 1956), 25.

67. Ibid., 5 . 
certain areas of the valley, yet "the evidence does not indicate that there has been significant net aggravation of the overall drainage problems nor impaired productivity of lands."68 Although salt levels in valley waters - a sign of groundwater augmentation increased after the 1930s, Maierhoffer pointed out that the number of acres taken out of production had "decreased to zero in 1953."69

YCWUA leaders viewed the salinity crisis of 1961 as an opportunity to obtain federal help. Initially, however, Sam Dick, YCWUA president, believed that the "international" problem would retard resolution of the Yuma Valley situation. Furthermore, USBR officials wanted to propose "a permanent solution" to Yuma's drainage problems only after the Arizona vs. California case had been settled by the Supreme Court. Nevertheless, Dick believed that "the permanent solution to that problem, involving so many complex factors, may not be found for some time." He lamented the exorbitant costs incurred by the existing drainage system, which had been paid for by the farmers. Dick also enumerated the benefits Mexico reaped from Valley efforts to regulate the water table. In 1961, for example, the YCWUA delivered 133,000 acre-feet of water to Mexico, which also required the use of millions of kilowatts of electricity to operate the system. The Mexican government paid a paltry $\$ 4,000$ for these benefits. "The Association thus finds itself in the position of having, at its own cost and expense," he noted, "delivered to Mexico in 1961 as a credit to the Mexican Treaty almost $10 \%$ of the amount required to be delivered to Mexico under the terms of that Treaty." To add insult to injury, collection of drainage and groundwater resources provided Mexico with "a large proportion of the water which comes from outside sources." Dick felt that the Association should be reimbursed for past expenses related to services rendered in fulfillment of the treaty. He argued that the expenses qualified for reimbursement under the Colorado River Front Work and Levee Systems Act, which provided for "constructing, improving, extending, operating and maintaining protection and drainage works and systems along the Colorado River." "70 In a February 6, 1963 meeting with USBR Commissioner Floyd Dominy, Dick discussed two plans for alleviating the drainage problems. The more extensive plan called for 60 additional wells at a cost of \$22 million. The "reduced" plan called for eighteen wells and was projected to cost between eight and nine million dollars. Commissioner Dominy preferred the more modest plan, noting however, that it "could be expanded later."71

Despite the loud approval of YCWUA leaders for the drainage wells and pumps, some local residents questioned the high capital outlay required for such an undertaking and the environmental propriety of the project. Local resident H. M. Corey refuted the need for "the big eight and a half million dollar boondoggle drainage plan." Corey believed that the YCWUA Board of Governors was merely holding out on completing immediate drainage projects in the Valley in order that the federal government would pay for a much grander project. "It is the opinion of our board of governors and the president," Corey noted, "that they would rather wait on this eight and one half million of non reimbursable money which would cause us not to spend our own sixty-one thousand."

68. Ibid., 42-43.

69. 46-49.

70. Letter from Sam Dick to A. B. West, October 12, 1962, John J. Rhodes Papers, MS 2, Box 88:35, Folder 3, Hayden Library, ASU.

71. Letter from H.M. Corey to John J. Rhodes, May 24, 1963, MS 2, Box 88:35, Folder 3. 
In contrast, Corey felt that if the association would expend $\$ 60,000$ to drain one specific portion of the valley, the association's problems would be solved "for a long time to come." Corey also felt that the drainage system endangered the agricultural viability of valley lands because most of the valley already had too little water in the water table. Nevertheless, Corey astutely perceived the political forces at play in proposing a massive drainage project. "The [USBR] is overstaffed," he wryly noted, "and they have to find projects to work on." The local Chamber of Commerce would also be delighted with the influx of contracts and construction teams that would pump money into the local economy. Corey found it ironic that despite nearly twenty years of lobbying for relief from the water table, Yuma farmers "seem[ed] to be farming ... regardless." "72

Rumors of intensive groundwater pumping on the Mexican side of the international boundary provided Yuma leaders with an argument that helped them obtain the needed drainage system. Geographically, the underground aquifer extended across the international border. As water seeped from the Yuma Mesa down to Yuma Valley, gravity enticed it across the border into Mexico. Even in the 1950s, when Congressman Anderson of New Mexico did not believe the YCWUA merited federal assistance for the drainage problems, he did feel that pumping water to prevent the Mexicans from using it provided "just cause" for governmental help. Merely mentioning possible benefits for Mexico from natural resources originating in the United States increased the willingness of some United States politicians to approve a given bill they would have originally opposed. At the Yuma Groundwater hearings Congressman Anderson asked Engineer Maierhoffer:

If you do not pump these large quantities of water from the lower gravel strata, which is about at sea level, would there not be a tendency that that water, if not intercepted, would just naturally flow into Mexico and you would get no credit for it under the treaty?

Maierhoffer responded, "Very definitely."73 Anderson believed that in such a situation, "the United States government might be able to pick up some of this excess water" to satisfy the Mexican Water Treaty. ${ }^{74}$ In the West, water was not simply a resource. It was the fundamental expression of civilization during the twentieth century. Symbolically and economically, it was a tool of power. Withholding water from Mexico, either in the form of surface or groundwater, was the goal of not a few politicians throughout the basin who believed those resources belonged solely to the United States.

By 1963, local, state, and national leaders emphasized the magnitude and importance of Yuma's drainage problems. The attention of the state's congressional delegation brought federal assistance a step closer to reality. In a confidential memo to Arizona's congressional representatives, W.S. Gookin, Arizona State Water Engineer, apprised state leaders of the need to support funding measures for a drainage project similar to that discussed by Dominy a year earlier in Yuma. Mexican farmers, he noted, "[were] rapidly and aggressively increasing their pumping through the drilling of new wells and subjugation of new land." If nothing were done to combat the new pumping, he feared that Mexican farmers might pump up to 1.5 million acre-feet of water per year.

72. Ibid.

73. Yuma Drainage Hearings, 50-51.

74. Ibid. 
Gookin feared that such events would affect underground resources in Yuma Valley. "The water underlying the Yuma area will be drawn into Mexico," he observed. Instead of allowing Mexico to proceed unchallenged, the state water engineer believed that this water should be "pumped by the U.S. and delivered to Mexico as surface water in satisfaction of the Mexican [treaty]." Finally, he warned that state and national interests would probably clash in the process of seeking approval for additional drainage wells. "It is my understanding," Gookin wrote, "that the State Department is unsympathetic with western water problems and seeks to assist agricultural interest in Mexico." He also feared that Secretary of State Dean Rusk and President Johnson would canvas support for "noninterference with Mexican agricultural interest." Ever mindful of how such developments might threaten Arizona, Gookin urged state representatives to fully support the project. $^{75}$

Arizona's congressional representatives successfully pushed legislation through Congress that authorized funds for the installation of seventeen drainage wells. Winning approval of the funds, however, did not simplify the complexities of water politics in Yuma County. International diplomacy infringed on local prerogatives in implementing the groundwater program. A confidential memo noted that placing all the wells in the valley would increase the salinity level of the river to levels greater than they had been prior to installation of the wells. ${ }^{76}$ The State Department had pledged to minimize salinity levels of water destined for Mexico. In light of that directive, USBR officials realized that it would be most effective to place eleven of the wells on Yuma Mesa and only six in Yuma Valley.

Senator Carl Hayden complained about the lethargic pace of installation of the wells. Hayden was deeply interested in the future of the Central Arizona Project (CAP), which was finally approved in 1968. Two weeks before Christmas in 1965, the powerful Senator expressed his plans to Stewart Udall, Secretary of the Interior. Water from the Yuma wells would not only help to fulfill the United States' obligations under the Mexican Water Treaty, Hayden believed, but it would ultimately free up higher quality water upstream for the CAP. Any further delay in placing the wells in Yuma Valley might allow Mexico to drain U.S. groundwater reserves. Hayden calculated that over 600 wells were currently being used south of the border to harvest over 800,000 acre- feet of water. He vigorously protested the notion that seventeen American wells could jeopardize Mexico's comparative advantage. Hayden lamented that "international politics rather than existing or incipient damage in Mexico" not only threatened Yuma County, but the state of Arizona at well. ${ }^{77}$

Despite the successful acquisition of six deep-drainage wells in 1966, the Colorado River Salinity Control Act provided the YCWUA with another opportunity to obtain additional assistance. Henry Brownell included an article to Minute 242 that placed a nonbinding limit of 160,000 acre-feet of water from the aquifer in the border region near Yuma. Although this article was intended to place a limit on overdraft pumping, it actually had the reverse effect. As a part of Title II, western leaders proposed that an extensive groundwater well field be constructed on a five-mile strip in Yuma County adjoining the

75. Memo from W. S. Gookin, December 7, 1963, Carl Hayden Papers, MS 1, Box 708, Folder 6.

76. Confidential Memo, Carl Hayden Papers, MS 1, Box 333, Folder 18.

77. Letter from Carl Hayden to Steward Udall, December 13, 1965, Carl Hayden Papers, MS 1, Box 333, Folder 18. 
Mexican border. Obtaining regional support was not difficult since every acre-foot of water pumped from below the ground freed up an equal amount of water somewhere in the Upper and Lower Basin for use elsewhere. Archie Mellon, President of the YCWUA, supplicated the Senate Committee to reimburse the YCWUA for their previous expenses in operating the Boundary Pumping Plant and drainage system. He reiterated that past

drainage problems had been caused by adjoining reclamation projects in Yuma County. ${ }^{78}$

YCWUA's support for Title II developed over the course of three decades. During that time a domestic problem with drainage patterns metamorphosed into an international pumping war. While the organization did not receive compensation for past expenses, the well field was constructed on five miles of land in Southern Yuma County. Ironically, as pumping increased during the early 1970s, YCWUA leaders were concerned that too much water was being extracted from the binational aquifer. International concerns over excessive pumping continued until the early 1980s. Since the article related to groundwater pumping in Minute 242 was nonbinding, it did nothing but send a tremor of fear through regional farmers as to the extent of the aquifer's water reserves. As a result, pumping continued. In retrospect, perhaps no other facet of the Colorado River Salinity Control Act illustrates how well local leaders adapted a recurring problem to a regional and national interest.

\section{First In Time, Last in Line: Water and Development on the Cocopah Reservation}

The proposed desalination plant also threatened developmental interests of Native Americans in Yuma County. The Cocopah Indians were the first known inhabitants of the Colorado River Delta. They migrated to the area around $1000 \mathrm{AD}$ and established settlements near the mouth of the Colorado River. ${ }^{79}$ Although the Cocopah were organized as a tribe by the United States government in 1917, they continued to cross the Mexican-American border to interact with the Cocopah in the Mexican Delta. During the early 1900s, members of the Cocopah tribe provided much of the back breaking manual labor needed to construct irrigation ditches, canals, and dams, in the Imperial and Yuma Valleys. Unfortunately, they were not included in the rush to develop the land for their own benefit. The farming and irrigation bonanza of the early twentieth century left them nearly destitute of arable land. Even if they would have owned extensive holdings of land, it is doubtful whether or nor the Bureau of Indian Affairs (BIA) and the USBR would have administered their water rights in their best interests. ${ }^{80}$

By 1974, economic development on the Cocopah reservation lagged far behind even the most modest standards realized throughout the rest of Yuma County. In a letter to Stan Womer, Federal Co-Chairman of the Four Corners Regional Commission, Hawley Atkinson, Special Assistant to Tribal Chairman Robert S. Barley, pointed out that not only was the tribe "destitute," but that it "has been passed and forgotten for nearly a 100

78. Senate Hearings, 341-342.

79. William Kelly, Cocopah Ethnography (Tucson: University of Arizona Press, 1977).

80. See Robert Bee, Crosscurrents Along the Colorado: The Impact of Government Policy on the Quechan Indians (Tucson: University of Arizona Press, 1981). Bee discusses the corrupt methods used by the BIA to take land and water benefits from the Quechan (Yuma) Indians and give them to Anglo farmers in Yuma County. 
years." ${ }^{.81}$ Atkinson claimed that unemployment levels of the reservation were as high as 75 percent. He went on to describe existing living conditions:

The people live in substandard housing; have substandard water supplies; no adequate sanitation facilities; poor health; lack of educational facilities; and the epitome of substandard facilities. The only new facilities is [sic] the "Cry House"at least their "wailing wall" is modern. Their evidence of deep abiding faith in God is reflected in this priority. ${ }^{82}$

To add insult to injury, prayer was about the only type of long-distance communication feasible on the reservation. The East Cocopah tribal community lacked telephone service. Chairman Barley lamented the fact that "there is only one payphone for all the families that live on the East reservation." 83

Despite these shortcomings, Chairman Barley hoped to achieve new levels of economic development on the reservation. In addition to importuning Arizona's Governor Williams for assistance in obtaining essential services for tribal members, Barley hoped to develop recently acquired land for agricultural production. The tribe also planned to create a recreation site on tribal lands located directly on the Colorado River. However, the canal designated to transport rejected saline water from Wellton-Mohawk to the Gulf of California intersected the reservation "on a line roughly parallel to the Colorado River." Barley apprised the Senate Committee that the canal would not only "deprive the Tribe of desperately needed acreage, but it will pose a formidable barrier, dividing the main portion of the Reservation from the accreted lands that have just recently been won in court." Barley worried that the desalinization plant might deprive the main channel of the river of water throughout the year. He concluded that the proposed recreation site would be "diminished, and probably eliminated, if the river no longer flows by the Reservation." 84

Barley's testimony illustrated the battle that Native Americans faced as they attempted to develop their communities in a high-specialized economy. He noted that the tribe fought for ten years to acquire an additional 800 acres. Barley recognized that the recent triumph was a Pyrrhic victory because the tract included "a railroad levy and a floodplain levy." Barley demanded that if the wastewater canal could not be moved, the tribe be compensated for the fragmentation of their land. He also argued that their land could not be used without their consent. Similar to arguments used by other organizations in Yuma County, Barley contended that "The United States government should not attempt to meet its treaty obligations to Mexico by ignoring its trusteeships to the Cocopah Tribe." Even if the Cocopah had not attained levels of socioeconomic development comparable to their Anglo neighbors, they were equally astute in legal matters related to water and land rights. In exchange for the land where the canal would intersect tribal lands, Barley suggested that 720 acres of federal land to the south of the reservation be transferred to the Tribe. ${ }^{85}$

81. Letter from Hawley Atkinson to Stan Womer, December 3, 1973, Governor's Office Record Group, Box 726, Arizona Department of Library, Archives, and Public Records (ADLAPR), Archives Division, Phoenix, Arizona.

82. Ibid.

83. Letter from Robert S. Barley to Governor Jack Williams, Governors Office Record Group, Box 726, ADLAPR, Archives Division.

84. Senate Hearings, 263. 
In addition to the land, the tribe asked that three bridges be built "over the portion of the reject stream [that] crosses the Reservation of the Cocopah Tribe of Indians." 86 The Cocopah felt these measures would "constitute full and just payment ... for the rights of way required for construction of the reject brine channel and appurtenant electrical transmission lines. ${ }^{\circ 7}$ In sum, Barley's testimony epitomized the local complexity of the Salinity Control Act, as well as a new age in Native American efforts to achieve a selfdetermined destiny. Instead of being wards of Congress, some tribes threatened to use the courts as a way to defend and augment their resources. As a result of their protest, the Cocopah Tribe was given alternative government lands. The Department of the Interior also built the three bridges that the tribe requested. For once, their voices did not go unheard.

\section{Conclusion: International Decisions, Local Consequences}

Chaos theorists often cite the "butterfly effect" as an example of how small changes can exercise a disproportionate influence throughout an entire system. ${ }^{88}$ In the late 1950 s, such an event took place in the Wellton-Mohawk Valley as a new canal transporting water to the salt-laden fields unexpectedly exacerbated drainage problems on the project. USBR Commissioner Dexheimer noted the deficiencies and complexities of the drainage system in Wellton Mohawk as early as 1957. "Correction of the drainage system is extremely complex," he confided to Senator Hayden. "The drainage problem in the Yuma area is but one of a number of water management problems." ${ }^{\circ 9} \mathrm{He}$ recognized that a sense of ecological order existed, yet he pointed out that the USBR did not understand the ecological relationships well enough to combat the problems that were quickly multiplying. "With the irrigation of land under the Gila Project have come drainage problems. In nearly all cases these problems were expected, but the rapidity with which they developed was not expected." 90

By 1961, salinity levels exercised palpable effects in Mexico and Southern Arizona, as saline water continued to drain from the Wellton-Mohawk project into the Colorado River. Ecologically, the drainage water exacerbated already increasing levels of salt pollution in the main channel of the Colorado River. The emissions not only damaged water quality in the United States, but they also endangered the well being of farmers and citizens in the Mexicali Valley. Politically, the event reverberated throughout the basin, on both sides of the border, and grabbed the attention of national leaders. Over time the issue played a significant role in the nature of Mexican-American relations.

Efforts to resolve the crisis also underscored the complexity of politico-ecological systems in the binational basin. Hundreds of dynamic political, economic, and ecological variables defined this nonlinear system. Furthermore, human agency and deep historic relations between the United States and Mexico provided room for variation, creation, and

85. Ibid., 265.

86. Ibid., 267.

87. Ibid.

88. For an excellent discussion of chaos theory, see James Gleick, Chaos: Making a New Science (New York: Viking: 1987).

89. Letter from W.A. Dexheimer to Carl Hayden, February 4, 1957, Carl Hayden Papers, MS 1, Box 479, Folder 7.

90. Ibid. 
conflict in the system. Slight changes in any variable could influence the nature of diplomatic relations between the two countries. For example, approval of the CAP in 1968 altered the perspective of western politicians towards Mexico and the rest of the basin. This accounted for the unprecedented sense of "harmony" displayed by community and state leaders from the basin. Personality also played a significant role. The uncanny ability of Herbert Brownell to deal with leaders from Mexico and the western states fostered a sense of international and domestic rapprochement. Therefore, dynamic changes throughout the system prior to the hearings played a significant role in shaping the nature of the legislative and diplomatic solutions to the problem.

Overwhelming congressional approval of Minute 242 brought the salinity crises to a point of diplomatic closure on June 11, 1974. ${ }^{91}$ Nevertheless, Minute 242 did not blot out the memories of how irrigated agribusiness went awry in the Wellton-Mohawk Valley during the 1950s. In fact, historians, environmentalists, and politicians are quick to point to the valley's misfortunes whenever they choose to explain the metamorphosis of water projects into pork barrels. ${ }^{92}$ For many, the $\$ 260$ million desalination plant embodied the cardinal defects of a growth-driven generation. With the added programs of the Salinity Control Act, the total cost approached $\$ 1$ billion. Ironically, at least one scientist noted that better water management in Yuma County alone might have dropped the salinity content of local return flows by at least 40 percent. He also noted that buying out the lands in question would be more economical after a decade than operating the plant. ${ }^{93}$

Despite overwhelming approval by Congress for the Salinity Control Act, construction of the desalination plant faced numerous hurdles. Although originally set to go on-line in 1981, rising costs, funding problems, and design reviews pushed the completion back more than a decade. The complex was finally completed in 1992. By that time, drainage waters from the Wellton-Mohawk Valley had unexpectedly rejuvenated the marshlands in the Cienega de Santa Clara in the Mexican portion of the delta. Environmentalists noted that operation of the desalination plant would replace those saline flows with brine waters, posing a possible threat to waterfowl migrating on the Pacific flyway. The greatest irony of the interlude between passage of the Salinity Control Act and completion of the plant related to increases in precipitation and water flows in the Colorado River. Additional amounts of water decreased the salinity level of water reaching Mexico and diluted the runoff from Wellton-Mohawk. In the face of chronic budget restraints, the USBR welcomed this natural solution to the salinity crisis. The plant has never operated at fullcapacity since its completion. Instead, improved desalination techniques are tested and limited quantities of treated water are offered for sale on the plant's Internet site. Furthermore, excess flows in the delta also quelled the groundwater pumping wars in the region. Increased aridity, however, may at any time require further decisions to be made regarding the resolution of salinity problems in the region, as well as limits on groundwater extraction by Mexico and the United States. ${ }^{94}$

Finally, the salinity crisis and Salinity Control Act reflect the inherent complexity found at each political level in the Colorado River Basin. Geopolitical specificity does not diminish the complex fabric of the model. In other words, local politics in the Colorado

91. Fradkin., 315.

92. Reisner ,309.

93. See W.E. Martin, "Economic Magnitudes and Economic Alternatives in Lower Basin Use of Colorado River Water," Natural Resources Journal, 1975, volume 15:1, 229-239. 
River Delta possessed just as many nuances and interested parties as the national and international levels. And as anthropologist James B. Greenberg has noted elsewhere, the "territorialization" and "commoditization" of the Colorado River Delta have placed local communities and ecosystems at the mercy of distant political interests, agencies, and communities that have less of an interest in the well-being of the region as they do in their own priorities which depend, nonetheless, on water from the distant river. ${ }^{95}$ Thus, the Salinity Control Act not only reflects the local complexity of the salinity crisis and its aftermath, but ultimately underscores the challenges that face present-day policy makers faced with the difficult task of fashioning basin-wide initiatives that balance diplomatic, national, regional, and local priorities in the face of ecological crises. As local stakeholders are given a larger role in crafting decisions that affect their communities, there is a greater chance that the needs of all involved, including the river itself, will be equitably distributed.

\section{References Cited}

Atkinson, Hawley.

1973. Letter to Stan Womer. December 3. Governors Office Record Group. Box 726. Arizona Department of Library Archives, and Public Records (ADLAPR). Archives Division. Phoenix.

Atomic Energy Commission.

1968. Nuclear Power and Water Desalting Plants for Southwest United States and Northwest Mexico, Preliminary Assessment Conducted by the Joint United StatesMexico-International Atomic Energy Agency Study Team. Executive Summary. September 1968. Washington D.C.: GPO.

94. For more on the history of the desalination plant and contemporary issues, see "Yuma Desalting Plant Limping Forward," Engineering News-Record, May 20, 1982, 26; "Yuma Desalter finally on Track; World's Largest Brackish Water Plant Due for Completion in '89," Engineering News-Record, April 18, 1985; Jennifer Warren, "Yuma Desalination Plant Comes of Age - Too Late; Colorado River: Project is Opening 14 Years Behind Schedule. Onetime ‘Showpiece' May be Obsolete,” Los Angeles Times, March 8, 1992, A1; Martin Van Der Werf, "Desalting Plant: White Elephant of Desert; \$256 Million Facility Sits Idle Outside Yuma," Arizona Republic, November 14, 1993, A8; One reader responds to Van Der Werf's article in "The Reason We Built the Yuma Plant," Arizona Republic, November 29, 1993, B17; Recent developments at the plant are discussed in Steve Larue's, "Technology on Tap; New Water Treatments may Offer a Clearer Solution," The San Diego Union-Tribune, April 22, 1998, E1; The USBR's Yuma Area Office advertises desalinated water on its web site at www.yao.lc.usbr.gov/forsale.htm, April 22, 1999; The consequences of operation of the desalting complex for the Cienega de Santa Clara are discussed in Edward P. Glenn, et.al., "Effects of Water Management on the Wetlands of the Colorado River Delta, Mexico," Conservation Biology, volume 10:4, August 1996, $1175-1185$.

95. See Greenberg, 133-149. 
Barley, Robert S.

1973. Letter to Governor Jack Williams. 1973. Governors Office Records Group. Box 726. ADLAPR. Archives Division.

Bee, Robert.

1981. Crosscurrents on the Colorado: The Impact of Government Policy on the Quechan Indians. Tucson: University of Arizona Press.

Brownell, Herbert with John P. Burke.

1993. Advising Ike: the Memoirs of Attorney General Herbert Brownell. Lawrence, KS: University of Kansas Press.

Central Arizona Project Association Papers.

No date. MS 100. Box 29. Folder 6. Hayden Library. Arizona State University. Confidential Memo (author unknown).

No date. Carl Hayden Papers (hereafter cited as MSI). MS I. Box 333. Folder 18. Hayden Library.

Corey, H.M.

1963. Letter to John J. Rhodes. May 24, 1963. John J. Rhodes Papers (hereafter cited as MS 2). MS 2. Box 88:35. Folder 3. Hayden Library.

Department of Interior.

1963. Minutes of Meeting, re: Yuma Valley Drainage Problem. February 6. MS 2. Box 88:35. Folder 2.

Dexheimer, W.A.

1957. Letter to Carl Hayden. February 4, 1957. MS I. Box 479. Folder 7.

Dick, Sam.

1962. Letter to A.B. West. October 12,1962. MS 2. Box 88:35. Folder 3.

Fradkin, Philip.

1981. A River No More: The Colorado River and the West. New York: Knopf.

Freuenfelder, Henry.

1945. Letter to Senator Ernest McFarland. April 4. Yuma County Water User's Association Papers. Yuma, Arizona.

Glenn, Edward P ., Richard S. Felger, Alberto Burquez, and Dale S. Turner.

1992. Cienega de Santa Clara: Endangered Wetland in the Colorado River Delta, Sonora, Mexico. Natural Resources Journal. 32:817-824.

Gookin, W.S.

1963. Memo. December. MS I, Box 708, Folder 6.

Greenberg, James B.

1998. "The Tragedy of Commoditization: Political Ecology of the Colorado River's Destruction," in Research in Economic Anthropology. 19:133-149.

Hayden, Carl.

1965. Letter to Stewart Udall. December 13,1965. MS I. Box 333. Folder 18.

Hayes, Samuel P.

1987. Beauty, Health and Permanence: Environmental Politics in the United

States, 1955-1985. Cambridge: Cambridge University Press.

House Subcommittee on Water and Power Resources.

1974. Hearings before the Subcommittee on Water and Power Resources of the Committee of Interior and Insular Affairs. House of Representatives. 93rd Congress. 2nd Session. HR 12165 and Related Bills, Colorado River Basin Salinity Control Act. Washington D.C.: Government Printing Office (GPO). 
LaRue, Steve.

1998. "'Technology on Tap; New Treatments May Offer a Clearer Solution." San Diego Union-Tribune. April22. El.

Lucas, Ken.

1975. "Desalting the Wellton Mohawk." in Arizona Farmer-Ranchman. May. 1-4.

Kelly, William.

1977. Cocopah Ethnography. Tucson: University of Arizona Press.

Kemmis, Daniel.

1990. Community and the Politics ofPlace. Norman, OK: University of Oklahoma Press.

Martin, W .E.

1975. "Economic Magnitudes and Economic Alternatives in Lower Basin Use of Colorado River Water," in Natural Resources Journal. 15:1.229-239.

Office of Saline Water.

1972. Saline Water Conversion Summary Report, 1971-1972. Washington D.C.: GPO.

Pisani, Donald J.

1989. "The Irrigation District and the Federal Relationship: Neglected Aspects of Water History," in The Twentieth-Century West: Historical Interpretations. Gerald D. Nash and Richard Etulian, eds. Albuquerque: University of New Mexico Press. 257292.

Reisner, Marc.

1986. Cadillac Desert: The American West and Its Disappearing Water. New York: Viking.

Riding, Alan.

1989. Distant Neighbors. New York: Vintage Books.

Sale, Kirkpatrick.

1993. The Green Revolution: The American Environmental Movement, 1962-1992.

New York: Hill and Wang.

Senate Committee on Interior and Insular Affairs.

1956. Yuma, Arizona Groundwater Problems, Hearings. Washington D.C.: GPO.

Senate Subcommittee on Water and Power Resources.

1974. Hearings before the Subcommittee on Water and Power Resources of the Committee of Interior and Insular Affairs. United States Senate, 93rd Congress. 2nd Session. S. 1807, S. 2940, S. 3094, Salinity Control Measures on the Colorado River. Washington D.C.: GPO.

Tabor, C.C.

1975. Letter to Ken Lucas. May. MS2. Box 130. Folder 19.

Van Der Werf, Martin.

1993. "Desalting Plant: White Elephant in the Desert." Arizona Republic. November 14. A8.

Werley, Lenora.

1961. "U.S. Takes Sudden Interest in Mexicali Water." The Arizona Daily Star. December 17. Copy found in MSI. Box 253. Folder 8.

Winsor, Mulford, Jr.

1959. "Statement ofMulford Winsor, Jr., City of Yuma, Arizona." November 23. Winsor Family Papers. Yuma, Arizona. 


\begin{abstract}
"The Politics of Place": Domestic and Diplomatic Priorities of the Colorado River Salinity Control Act (1974)

This article analyzes the Colorado River Salinity Control Act (1974) from international, regional (Colorado River Basin), and local (Yuma County) perspectives. While the Nixon administration simply wanted appropriations to build a desalination plant near Yuma, Arizona, in order to respond to Mexican complaints of saline river water south of the border, regional (U.S.) leaders used the legislation to obtain additional salinity control measures that would ostensibly conserve the Colorado River Basin's shrinking water supply. The article also examines the efforts of farmers, municipal leaders, and Quechan natives in Yuma County to shape the legislation to their advantage.

Keywords: Environmental politics, Colorado River Delta, Yuma County, U.S.-Mexican Relations, Quechan Indians, desalination
\end{abstract}

\title{
Résumé:
}

"La politique de l'espace": les priorités diplomatiques et domestiques de la loi sur le contrôle de salinité du fleuve Colorado (1974)

L'article présente une analyse de la loi sur le contrôle de salinité du fleuve Colorado (1974) des points de vues international, régional (celui du bassin du fleuve Colorado), et local (celui du département de Yuma). Alors que l'administration de Nixon voulait simplement s'approprier des espaces pour construire une station de désalination près de Yuma, Arizona, afin de traiter les plaintes soulevées par le Mexique à propos de l'eau salin au sud de la frontière; les administrateurs régionaux américains ont utilisé la même législation pour augmenter les mesures de contrôle de salinité dans le but de conserver, d'une manière ostensible, la réserve d'eau du bassin du fleuve Colorado menacée par une pénurie constante de sa nappe. L'article examine aussi les efforts déployés par les agriculteurs, les chefs municipaux ainsi que les indigènes de Quechan dans le département de Yuma pour influencer cette législation à leur profit.

Mots Clefs: Les politiques de l'environnement, Delta du fleuve Colorado, département de Yuma, Les relations Mexico-Americaines, Les Indiens de Quechan, désalination.

\section{Resumen:}

" La política del lugar ": Prioridades diplomáticas y domésticas del acto del control de la salinidad del Río Colorado (1974).

Este artículo analiza el acto del control de la salinidad del Río Colorado (1974) (desde las perspectivas internacionales, regionales (la cuenca del Río Colorado), y locales (del condado de Yuma). Mientras que la administración de Nixon quiso simplemente que las apropiaciones construyeran una planta de desalación cerca de Yuma, Arizona, para responder a las quejas Mexicanas de salinidad del agua de río al sur de la frontera, los líderes regionales (de los E.U.A..) utilizaron la legislación para obtener medidas de control adicionales de la salinidad que aparentemente ayudaren a conservar el abastecimiento reducido de agua de la cuenca del Río Colorado. El artículo también examina los esfuerzos de granjeros, de líderes municipales, y del grupo indígena Cocopah en el condado de Yuma de manipular ésta legislación a su ventaja.

Palabras claves: Política ambiental, Delta del Río Colorado, Condado de Yuma, relaciones de U.S.-Mexico, Cocopah, desalinización 